\title{
Who Are the People of God?
}


This page intentionally left blank 


\title{
Who Are the People of God?
}

Early Christian Models of Community

\author{
Howard Clark Kee
}

Yale University Press New Haven and London 
Published with assistance from the Mary Cady Tew Memorial Fund.

Copyright $(1995$ by Yale University.

All rights reserved.

This book may not be reproduced, in whole or in part, including illustrations, in any form (beyond that copying permitted by Sections 107 and 108 of the U.S. Copyright Law and except by reviewers for the public press), without written permission from the publishers.

\section{Designed by Rebecca Gibb.}

Set in Weiss and Syntax types by Marathon Typography Service, Inc., Durham, North Carolina.

\section{Library of Congress Cataloging-in-Publication Data}

Kee, Howard Clark.

Who are the people of Cod? : early Christian models of community / Howard Clark Kee.

p. $\mathbf{c m}$.

Includes bibliographical refrences and index.

ISBN: 978-0-300-07063-7

1. People of God-History of doctrines-Early church, ca. 30-600. 2. ChurchHistory of doctrines-Early church, ca. 30-600. 3. Christianity-Origin. I. Title. BV598.K425 1994

$270.1-\mathrm{dc} 20$

94-13883

CIP

The paper in this book meets the guidelines for permanence and durability of the Committee on Production Guidelines for Book Longevity of the Council on Library Resources. 